\title{
Susac's syndrome as HIV-associated immune reconstitution inflammatory syndrome
}

\author{
Francesca Ferretti ${ }^{*}$, Simonetta Gerevini ${ }^{2}$, Bruno Colombo ${ }^{3}$, Manuela Testa ${ }^{1}$, Monica Guffanti ${ }^{1}$, Diego Franciotta ${ }^{4}$, \\ Gaetano Bernardi ${ }^{5}$, Adriano Lazzarin ${ }^{1}$ and Paola Cinque $^{1}$
}

\begin{abstract}
Susac's Syndrome (SS) is an autoimmune endotheliopathy of cerebral, retinal and cochlear arterioles. We report of an HIV-infected woman who developed a first SS episode following a spontaneous reduction of plasma viral load and several relapses six years later, following initiation of combined antiretroviral therapy (CART). Corticosteroids and intravenous immunoglobulins alone did not control the disease, which improved after combined treatment with acyclovir and ganciclovir. SS onset in HIV infection and relapses during CART-induced immune reconstitution are consistent with the dysimmune nature of the disease. The response to anti-herpes drugs suggests a viral contribute in this case of SS.
\end{abstract}

\section{Introduction}

Susac's syndrome (SS) is a rare autoimmune microangiopathic disorder, affecting precapillary arterioles of the brain, retina and cochlea [1]. Until now, approximately 200 cases have been reported [2], mainly in women. Headache, focal neurological signs, deafness and ocular symptoms are the most common clinical manifestations, but do not necessary occur simultaneously. SS is almost never fatal [3], however it is characterized by spontaneous remissions and relapses that can only partially be controlled or delayed by immunosuppressive drugs and often lead to irreversible neurological sequelae and poor quality of life.

We here describe a case of SS in an HIV-infected woman, who developed a first episode following a spontaneous decrease of plasma viral load, and several relapses 6 years later, following introduction of combined antiretroviral therapy (cART), as likely expression of an immune reconstitution inflammatory syndrome (IRIS). Notably, the neurological picture was not controlled by corticosteroids and intravenous immunoglobulins alone, but only when acyclovir and ganciclovir were administered concomitantly, suggesting a possible role of herpes viruses in SS pathogenesis in this case.

\footnotetext{
*Correspondence: ferretti.francesca@hsr.it

'Department of Infectious Diseases, San Raffaele Scientific Institute, Milan, Italy

Full list of author information is available at the end of the article
}

\section{Case report}

In September 2002, a 42 year-old woman with a 15-year history of untreated HIV-1 and hepatitis C virus infection was admitted to our Infectious Diseases Department with headache, facial paresthesias, amaurosis, hemianopsia, tinnitus and vertigo (Table 1). Blood CD4+ cells were $355 / \mu \mathrm{L}$ and plasma HIV-RNA level had unexplainably dropped from 270,000 to 2000 copies/mL in the previous 9 months, in absence of ART. Brain magnetic resonance imaging (MRI) showed T2-hyperintense lesions in the basal ganglia, bilateral subcortical and deep cerebral white matter and medium-posterior corpus callosum, some of which were gadolinium enhancing (images not available). Cerebrospinal fluid (CSF) analysis showed only mild pleocytosis and protein increase, fundus oculi examination a retinal vascular occlusion in the superior temporal regions, audiometric examination a neuro-sensorial left hypoacusia. The diagnosis was of cerebral vasculitis and suspected cytomegalovirus (CMV) retinopathy. Intravenous (i.v.) methylprednisolone and gancyclovir were administered (Table 1), followed by clinical resolution.

The patient remained asymptomatic for six years, with MRI showing persistence of inactive brain lesions. In January 2008 she started treatment with tenofovir, emtricitabine and unboosted atazanavir and in 4 weeks CD4+ cells increased from 202 to $260 / \mu \mathrm{L}$ and HIV-RNA dropped from $13,000 \mathrm{c} / \mathrm{mL}$ to undetectable $(<50 \mathrm{c} / \mathrm{mL})$. In March 2008, after 6 weeks of cART, she presented
C Biomed Central

(c) 2013 Ferretti et al.; licensee BioMed Central Ltd. This is an Open Access article distributed under the terms of the Creative Commons Attribution License (http://creativecommons.org/licenses/by/2.0), which permits unrestricted use, distribution, and reproduction in any medium, provided the original work is properly cited. 
Table 1 Clinical, laboratory, neuroradiological findings and therapies for each Susac Syndrome episode

\begin{tabular}{|c|c|c|c|c|c|c|c|}
\hline Date & $\begin{array}{l}\text { New neurological } \\
\text { symptoms }\end{array}$ & $\begin{array}{l}\text { Laboratory } \\
\text { examinations }\end{array}$ & Brain MRI & Other examinations & $\begin{array}{l}\text { Ongoing therapy } \\
\text { (duration) }\end{array}$ & New therapy (duration) & $\begin{array}{l}\text { Clinical } \\
\text { Outcome }\end{array}$ \\
\hline \multirow{10}{*}{$\begin{array}{l}\text { First episode } \\
\text { September } 2002\end{array}$} & \multirow{10}{*}{$\begin{array}{l}\text { Headache, facial } \\
\text { paresthesias, } \\
\text { hemianopsia, } \\
\text { amaurosis, } \\
\text { tinnitus, vertigo }\end{array}$} & Blood & \multirow{10}{*}{$\begin{array}{l}\text { T2-hyperintense } \\
\text { Gd-enhancing } \\
\text { lesions (brain) }\end{array}$} & \multirow{10}{*}{$\begin{array}{l}\text { FO and RFA: retinal } \\
\text { branch occlusion. } \\
\text { Auditory examination: } \\
\text { initial left neurosensorial } \\
\text { hypoacusia. VEP, AEP: normal }\end{array}$} & \multirow[t]{10}{*}{ None } & \multirow{10}{*}{$\begin{array}{l}\text { IV MEP } 20 \text { mg bid ( } 3 \text { days). } \\
\text { IV GCV } 5 \text { mg/Kg bid ( } 14 \text { days) }\end{array}$} & \multirow[t]{10}{*}{ Resolution } \\
\hline & & $\mathrm{CD} 4+: 355 / \mu \mathrm{L}$ & & & & & \\
\hline & & $\mathrm{VL}: 2000 \mathrm{c} / \mathrm{mL}$ & & & & & \\
\hline & & $\begin{array}{l}\text { VDRL and } \\
\text { TPHA neg }\end{array}$ & & & & & \\
\hline & & CSF & & & & & \\
\hline & & Cells: 5/mL & & & & & \\
\hline & & $\begin{array}{l}\text { Proteins: } \\
89 \mathrm{gr} / \mathrm{dL}\end{array}$ & & & & & \\
\hline & & Microbiology * neg & & & & & \\
\hline & & Viral genomes ${ }^{* *}$ neg & & & & & \\
\hline & & $\mathrm{VL}<50 \mathrm{c} / \mathrm{mL}$ & & & & & \\
\hline \multirow{4}{*}{$\begin{array}{l}\text { First relapse } \\
\text { March } 2008\end{array}$} & \multirow{4}{*}{$\begin{array}{l}\text { Headache, facial, } \\
\text { lingual, oral and } \\
\text { hand paresthesias }\end{array}$} & Blood & \multirow{4}{*}{$\begin{array}{l}\text { Increased T2 } \\
\text { hyperintensity of } \\
\text { old lesions; new T2 } \\
\text { hyperintense non } \\
\text { Gd-enhancing lesion } \\
\text { (brain) (Figure 1a) }\end{array}$} & \multirow{4}{*}{$\begin{array}{l}\text { EEG: focal slow abnormal } \\
\text { activity in the left temporal region }\end{array}$} & \multirow{4}{*}{$\begin{array}{l}\text { CART: TDF, FTC, } \\
\text { ATV ( } 6 \text { weeks })\end{array}$} & \multirow{4}{*}{$\begin{array}{l}\text { Oral PDN } 50 \mathrm{mg} \text { qd } \\
\text { ( } 5 \text { days), then } 25 \mathrm{mg} \text { qd } \\
\text { ( } 3 \text { days). Stop cART }\end{array}$} & \multirow[t]{4}{*}{ Worsening } \\
\hline & & 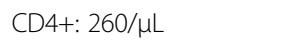 & & & & & \\
\hline & & $\mathrm{VL}<50 \mathrm{c} / \mathrm{mL}$ & & & & & \\
\hline & & $\begin{array}{l}\text { VDRL and } \\
\text { TPHA neg }\end{array}$ & & & & & \\
\hline \multirow{8}{*}{$\begin{array}{l}\text { First relapse, } \\
\text { follow-up } \\
\text { (SS diagnosis) } \\
\text { April } 2008\end{array}$} & \multirow{8}{*}{$\begin{array}{l}\text { Left hemiparesis, } \\
\text { acute left } \\
\text { hypoacusia }\end{array}$} & CSF & \multirow{8}{*}{$\begin{array}{l}\text { Further increased } \\
\text { T2 hyperintensity of } \\
\text { old lesions; new T2 } \\
\text { hyperintense non } \\
\text { Gd-enhancing lesions } \\
\text { (cerebellum) (Figure 1b) }\end{array}$} & \multirow{8}{*}{$\begin{array}{l}\text { Visual field: central scotoma of right } \\
\text { eye, arcuate scotoma in the superior } \\
\text { and inferior field of left eye. FO: right } \\
\text { retinal vasculopathy. RFA: acute bilateral } \\
\text { retinal vasculitis with reduced perfusion. } \\
\text { VEP: absent response of right eye, } \\
\text { reduced response of left eye; AEP: } \\
\text { mixed bilateral hypoacusia. }\end{array}$} & \multirow[t]{8}{*}{ None } & \multirow{8}{*}{$\begin{array}{l}\text { IV MEP } 1 \mathrm{~g} \text { gd ( } 5 \text { days), } \\
\text { then oral PDN } 50 \mathrm{mg} \text { qd } \\
\text { (10 days). CART: TDF, FTC, ATV }\end{array}$} & \multirow{8}{*}{$\begin{array}{l}\text { Transient } \\
\text { improvement }\end{array}$} \\
\hline & & Cells: $1 / \mathrm{mL}$ & & & & & \\
\hline & & $\begin{array}{l}\text { Proteins: } \\
23 \mathrm{~g} / \mathrm{dL}\end{array}$ & & & & & \\
\hline & & Viral genomes*: neg & & & & & \\
\hline & & Oligoclonal bands: neg & & & & & \\
\hline & & lgG: 64 mg/dL & & & & & \\
\hline & & Albumin ratio: 4.52 & & & & & \\
\hline & & $\begin{array}{l}\text { Intrathecal } \\
\text { HSV-1/2, VZV and } \\
\text { CMV-specific lgG } \\
\text { synthesis: neg }\end{array}$ & & & & & \\
\hline $\begin{array}{l}\text { Second relapse } \\
\text { April } 2008\end{array}$ & $\begin{array}{l}\text { Blurred vision, } \\
\text { hallucinations, } \\
\text { gait and balance } \\
\text { deficit }\end{array}$ & $\begin{array}{l}\text { Blood c-ANCA, } \\
\text { p-ANCA, anti } \\
\text { cardiolipin, anti-beta } \\
\text { 2-gp, LA and ANA: neg }\end{array}$ & $\begin{array}{l}\text { New T2 hyperintense } \\
\text { lesions with mild } \\
\text { Gd-enhancement }\end{array}$ & & $\begin{array}{l}\text { CART: TDF, FTC, } \\
\text { ATV (3 weeks) }\end{array}$ & $\begin{array}{l}\text { IV MEP } 1 \mathrm{~g} \text { qd ( } 6 \text { days), } \\
\text { then oral PDN } 75 \mathrm{mg} \text { qd }\end{array}$ & $\begin{array}{l}\text { Transient } \\
\text { improvement }\end{array}$ \\
\hline \multirow{3}{*}{$\begin{array}{l}\text { Third relapse } \\
\text { May } 2008\end{array}$} & \multirow{3}{*}{$\begin{array}{l}\text { Worsening of } \\
\text { previous } \\
\text { symptoms }\end{array}$} & Blood & \multirow{3}{*}{$\begin{array}{l}\text { New Gd-enhancing } \\
\text { lesions (brain and } \\
\text { brain stem) (Figure 1c) }\end{array}$} & & \multirow{3}{*}{$\begin{array}{l}\text { CART: TDF, FTC, } \\
\text { ATV (6 weeks). } \\
\text { Oral PDN } 75 \text { mg qd } \\
\text { ( } 5 \text { days) }\end{array}$} & \multirow{3}{*}{$\begin{array}{l}\text { IV Ig } 15.5 \mathrm{~g} \text { qd ( } 5 \text { days). } \\
\text { IV MEP } 40 \text { mg bid ( } 6 \text { days) }\end{array}$} & \multirow[t]{3}{*}{ No changes } \\
\hline & & CD4+: $113 / \mu \mathrm{L}$ & & & & & \\
\hline & & $\mathrm{VL}<50 \mathrm{c} / \mathrm{mL}$ & & & & & \\
\hline
\end{tabular}


Table 1 Clinical, laboratory, neuroradiological findings and therapies for each Susac Syndrome episode (Continued)

\begin{tabular}{|c|c|c|c|c|c|c|}
\hline \multirow{3}{*}{$\begin{array}{l}\text { Third relapse, } \\
\text { follow-up } \\
\text { May } 2008\end{array}$} & \multirow{3}{*}{$\begin{array}{l}\text { Persistence of } \\
\text { symptoms }\end{array}$} & CSF & & \multirow{3}{*}{$\begin{array}{l}\text { CART: TDF, FTC, } \\
\text { ATV (8 weeks). } \\
\text { IV MEP } 40 \text { mg } \\
\text { bid ( } 6 \text { days) }\end{array}$} & \multirow{3}{*}{$\begin{array}{l}\text { IV MEP } 1 \mathrm{~g} \text { qd (3 days), } \\
\text { then oral PDN } 150 \mathrm{mg} \text { qd, } \\
\text { tapered to } 5 \mathrm{mg} \text { in } 16 \text { weeks. } \\
\text { IV GCV } 5 \mathrm{mg} / \mathrm{Kg} \text { bid ( } 14 \text { days), } \\
\text { then oral V-GCV } 450 \mathrm{mg} \text { qd } \\
\text { ( } 4 \text { weeks). IV ACV } 15 \mathrm{mg} / \mathrm{Kg} \\
\text { tid (14 days), then oral ACV } \\
800 \mathrm{mg} \text { q5 ( } 3 \text { weeks) }\end{array}$} & \multirow[t]{3}{*}{ Improvement } \\
\hline & & Cells: N.A. & & & & \\
\hline & & Proteins: $172 \mathrm{~g} / \mathrm{dL}$ & & & & \\
\hline \multirow{3}{*}{$\begin{array}{l}\text { Fourth relapse } \\
\text { November } 2008\end{array}$} & \multirow{3}{*}{$\begin{array}{l}\text { Vertigo, visus } \\
\text { deficit }\end{array}$} & Blood & New small & \multirow{3}{*}{$\begin{array}{l}\text { CART: TDF, } \\
\text { 3TC, ABV. Oral } \\
\text { PDN } 5 \text { mg }\end{array}$} & \multirow{3}{*}{$\begin{array}{l}\text { IV MEP } 1 \mathrm{~g} \text { qd ( } 3 \text { days). } \\
\text { IV ACV } 15 \mathrm{mg} / \mathrm{Kg} \text { tid } \\
\text { (14 days), then oral } \\
\text { ACV } 400 \mathrm{mg} \text { bid ( } 4 \text { weeks) }\end{array}$} & \multirow{3}{*}{$\begin{array}{l}\text { Improvement } \\
\text { and subsequent } \\
\text { stabilization }\end{array}$} \\
\hline & & 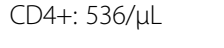 & lesions (cerebellum) & & & \\
\hline & & $\mathrm{VL}<50 \mathrm{c} / \mathrm{mL}$ & (Figure 1d) & & & \\
\hline
\end{tabular}

* Microbiology: microscopic and culture for bacteria, mycobacteria and fungi; ** Viral genomes: DNA of herpes simplex virus type 1 and 2 (HSV-1, HSV-2), varicella-zoster virus (VZV), cytomegalovirus (CMV), Epstein-Barr virus, JC virus.

VL HIV-RNA, VDRL Venereal disease research laboratory test, TPHA Treponema pallidum hemagglutination, neg Negative, CSF Cerebrospinal fluid, $p$-ANCA Perinuclear anti-neutrophil cytoplasmic antibodies, $c-A N C A$ Cytoplasmic anti-neutrophil cytoplasmic antibodies, anti-beta 2-gp Anti beta-2 glycoprotein, LA Lupus anticoagulant antibodies, ANA Antinuclear antibodies, N.A. Not available, MRI Magnetic resonance imaging,

Gd Gadolinium, FO Fundus oculi, RFA Retinal fluorangiography, VEP Visual evoked potentials, AEP Auditory evoked potential, EEG Electroencephalogram, CART Combination antiretroviral therapy, TDF Tenofovir,

FTC Emtricitabine, ATV Atazanavir, 3TC Lamivudine, ABV Abacavir, IV Intravenous, MEP Methylprednisolone, PDN Prednisone, IV Ig Intravenous immunoglobulins, GCV Ganciclovir, V-GCV Valganciclovir, ACV Aciclovir. 

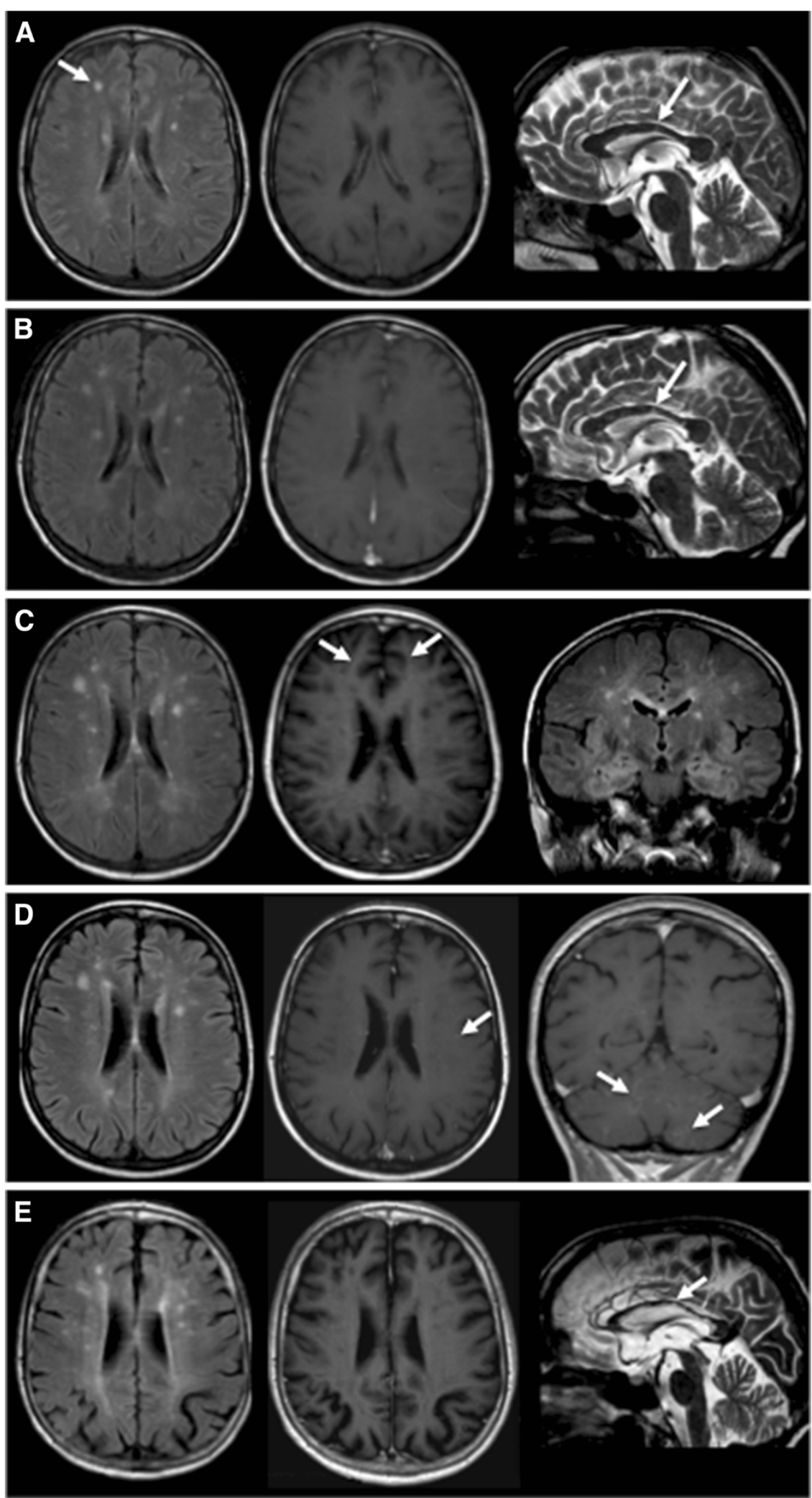

Figure 1 (See legend on next page.) 
Figure 1 Brain magnetic resonance imaging: axial FLAIR (first column), axial Gd -T1 (second column), sagittal T2 (third column: A, B, E), coronal FLAIR (C) or coronal Gd-T1 (D). A. March 14th, 2008 (first relapse): T2/FLAIR hyperintense non-enhancing lesions of centra semiovalia (arrow) and corpus callosum (arrow) white matter. B. April 1st, 2008 (first relapse, follow-up; diagnosis of SS): increased number and intensity of the T2/FLAIR hyperintense non-enhancing lesions of brain white matter, corpus callosum (arrow), also extending to cerebellum (not shown). C. May 15th, 2008 (third relapse): further increase of lesion number and intensity, some of the lesions are now enhancing (arrow). D. November 25th, 2008 (fourth relapse): stabilization of the supratentorial lesions, but new multiple contrast-enhancing brain (arrow) and cerebellar lesions (arrows). E. September 6th, 2012 (long-term follow-up): no evidence of disease activity with ensuing brain atrophy, as shown by dilatation of cortical sulci and loss of brain volumes, including at the corpus callosum (arrow).

with headache and paresthesias. Brain MRI showed increased T2 hyperintensity of old lesions and one new right frontal lesion, without contrast enhancement (Figure 1a). CNS-IRIS was suspected, patient was treated with oral prednisone and self-suspended cART. After three weeks, however, she was admitted to our department for worsening of previous neurological symptoms with new onset of hemiparesis and hypoacusia. Brain MRI showed further increased hyperintensity of old lesions and new non-enhancing T2 hyperintense cerebral and cerebellar lesions (Figure 1b). Fundus oculi examination showed right retinal vasculitis characterized by bilateral arteriolar wall hyperfluorescence and reduced perfusion at fluorangiography. Auditive evoked potentials confirmed the hypoacusia. SS was diagnosed based on current and retrospectively examined clinical and radiological findings along with exclusion of other central nervous system (CNS) diseases. The patient received high dose i.v. methylprednisolone with partial remission of symptoms and was discharged with maintenance oral prednisone. cART was restarted after four-weeks withdrawal.

In April 2008, three weeks after discharge, the patient was readmitted for new neurological symptoms and contrast-enhancing brain lesions at MRI (second relapse). She received high dose i.v. methylprednisolone, tapered with oral prednisone, followed by mild clinical improvement. A third relapse with new MRI contrast-enhancing lesions occurred in May 2008, while patient was still on maintenance oral prednisone (Figure 1c). She received i.v. immunoglobulin followed by $40 \mathrm{mg}$ bid of i.v. methylprednisolone, with no improvement. High dose i.v. methylprednisolone was then started. I.v. gancyclovir and acyclovir were also administered for the presence of CMV pp65 antigen in plasma (5 nuclei) and suspecting a reactivation of a viral infection of the CNS, in view of the response to gancyclovir during the first episode in 2002. Patient conditions improved substantially and she was discharged with oral maintenance prednisone, acyclovir and valgancyclovir. Acyclovir was continued for 3 weeks and valganciclovir was stopped after 4 weeks for hematologic toxicity. In August 2008 cART was switched to lamivudine, tenofovir and abacavir. A fourth relapse occurred seven months later, with new MRI contrast enhancing cerebral and cerebellar lesions (Figure 1d). Patient was treated with i.v. methylprednisolone and i.v. acyclovir for 14 days, followed by clinical and MRI improvement with no further relapses.

During the following years the patient continued cART and oral prednisone maintenance at $2.5-5 \mathrm{mg}$ per day, increased to $12.5-25 \mathrm{mg}$ for short periods, for worsening of vertigo. She experienced no new neurological episodes, but was left with severe neurological sequelae, iatrogenic diabetes and severe osteoporosis with vertebral fractures. At last visit in January 2013 the patient had mild cognitive impairment by neuropsychological evaluation, walked with a cane and suffered from severe visual and earing loss. There was no evidence of disease activity at MRI (Figure 1e), CD4+ were 574 cells $/ \mu \mathrm{L}$ and HIV-RNA $<50 \mathrm{c} / \mathrm{mL}$.

\section{Discussion}

This is, to our knowledge, the first case of SS described in an HIV-infected person. Our patient met all the diagnostic criteria for SS, i.e., MRI findings of corpus callosum microinfarctions, leptomeningeal enhancement and grey matter involvement, evidence of branch retinal artery occlusion at retinal fluorangiography and abnormal brainstem auditory evoked potentials [1]. In agreement with what often reported [4], diagnosis was achieved only years after onset, when the classical triad of cerebral, ocular and auditory involvement was documented, along with exclusion of other etiologies.

In our case, symptoms occurred in the peculiar context of immune reconstitution, which was apparently spontaneous at the onset of SS and associated with cART in the subsequent relapses, providing the criteria for IRIS [5]. IRIS consists of a broad spectrum of inflammatory diseases that present after starting an effective cART, leading to CD4+ cells increase and, more importantly, plasma HIV-RNA reduction. [6] IRIS reflects a paradoxycal inflammatory response to opportunistic pathogens, such as Cryptococcus spp [7], mycobacteria [8], JC virus [9], or also to auto-antigens $[10,11]$. Indeed, autoimmune diseases like Graves thyroiditis, pulmunary sarcoidosis, rheumatoid arthritis, systemic lupus erythematosus and polymiositis have been reported as IRIS manifestations [10]. The recent finding of anti-endothelium cell autoantibodies in some SS patients [12] and the usually good response to immunosuppressive therapy support the autoimmune pathogenesis of 
SS. Thus our case suggests that SS might represent an additional manifestation of "autoimmune IRIS".

Our patient did not show a long-lasting response to high dose i.v. steroids or i.v. immunoglobulins alone in three attempts (first and second relapses), whereas a substantial and durable improvement was achieved both times steroids were combined with antiviral drugs, i.e., acyclovir, active on herpes simplex virus type 1 and type 2 and varicella-zoster virus (VZV), and gancyclovir, also active on CMV and Epstein-Barr virus. It is known that the response to steroids in SS can not persist over time [13] and that SS can be characterized by spontaneous attenuation of the immunopathological process [3]. However, the temporal relationship between antiviral treatment and clinical improvement was strong and consistent in our case, suggesting that reactivation of an herpesvirus in the CNS might have contributed to disease pathogenesis.

We did not find evidence of herpesviruses in CSF (Table 1), but this does not exclude possible low level replication in CNS tissue [14]. We can speculate on a pathogenic model by which an herpesvirus reactivated in the context of immune reconstitution and, by replication in vascular cells [15] and consequent exposure of either viral or auto-antigens, lead to immune mediated damage of cerebral vessels. According to this model, antiviral therapy could have initially contributed to switch off the inflammatory stimulus by control of viral replication. A potential candidate herpesvirus is VZV. VZV can cause direct damage of CNS vessels of all calibres and indirect damage of CNS cells [16] and it is a well known cause of CNS vasculitis and ocular infections in HIV-infected subjects $[17,18]$. In addition, herpes zoster, resulting from peripheral VZV reactivation, is a frequent IRIS manifestation and cases of VZV CNS-IRIS have recently been reported $[19,20]$.

In conclusion, our case shows that SS may occur within a dysimmune context that is possibly sustained by HIV infection, cART-associated immune reconstitution, or both. The clinical and neuroradiological remission observed when antiviral drugs were added to corticosteroids support a potential pathogenetic role of herpes virus reactivations in SS in our case.

\section{Consent}

Written informed consent was obtained from the patient for publication of this Case report and any accompanying images. A copy of the written consent is available for review by the Editor-in-Chief of this journal.

\section{Competing interests}

The authors declare that they have no competing interests.

\section{Authors' contributions}

FF, BC, MG, AL and PC contribuited to the care of the patient, SG to neuroradiologic examination, MT, DF and GB to laboratory analyses. FF drew up the first draft of the report, DF and PC made a substantial contribution to draft the manuscript and revised the draft. All authors read and approved the final version of the manuscript.

\section{Acknowledgements}

The authors thank the medical and nursing staff at the Department of Infectious Diseases of San Raffaele Hospital for their assistance in the care of this patient. We also wish to thank the patient and her family for their collaboration.

\section{Author details}

${ }^{1}$ Department of Infectious Diseases, San Raffaele Scientific Institute, Milan, Italy. ${ }^{2}$ Unit of Neuroradiology, San Raffaele Scientific Institute, Milan, Italy. ${ }^{3}$ Department of Neurology, San Raffaele Scientific Institute, Milan, Italy. ${ }^{4}$ Department of Neurology, IRCCS, C. Mondino National Institute of Neurology, Pavia, Italy. ${ }^{5}$ Department of Neurology, IRCCS Neurologic Institute Carlo Besta Institute, Milan, Italy.

Received: 17 June 2013 Accepted: 24 August 2013

Published: 3 September 2013

\section{References}

1. Susac JO, Egan RA, Rennebohm RM, Lubow M: Susac's syndrome: 1975-2005 microangiopathy/autoimmune endotheliopathy. J Neurol Sci 2007, 257:270-272.

2. Rennebohm RM, Susac JO, Egan RA, Daroff RB: Susac's syndrome - update. J Neurol Sci 2010, 299:86-91.

3. Aubart-Cohen F, Klein I, Alexandra JF, et al: Long-term outcome in Susac syndrome. Medicine (Baltimore) 2007, 86:93-102.

4. Kleffner I, Duning $\mathrm{T}$, Lohmann $\mathrm{H}$, et al: A brief review of Susac syndrome. $J$ Neurol Sci 2012, 322:35-40.

5. French MA, Price $P$, Stone SF: Immune restoration disease after antiretroviral therapy. AIDS 2004, 18:1615-1627.

6. Shelburne SA, Visnegarwala F, Darcourt J, et al: Incidence and risk factors for immune reconstitution inflammatory syndrome during highly active antiretroviral therapy. AIDS 2005, 19:399-406.

7. Lortholary O, Fontanet A, Mémain N, et al: Incidence and risk factors of immune reconstitution inflammatory syndrome complicating HIV-associated cryptococcosis in France. AIDS 2005, 19:1043-1049.

8. Meintjes G, Lawn SD, Scano F, et al: Tuberculosis-associated immune reconstitution inflammatory syndrome: case definitions for use in resource-limited settings. Lancet Infect Dis 2008, 8:516-523.

9. Cinque P, Koralnik IJ, Gerevini S, Miro JM, Price RW: Progressive multifocal leucoencephalopathy in HIV-1 infection. Lancet Infect Dis 2009, 9:625-636.

10. Maganti RM, Reveille JD, Williams FM: Therapy insight: the changing spectrum of rheumatic disease in HIV infection. Nat Clin Pract Rheumatol 2008, 4:428-438.

11. Barber DL, Andrade BB, Sereti I, Sher A: Immune reconstitution inflammatory syndrome: the trouble with immunity when you had none. Nat Rev Microbiol 2012, 10:150-156.

12. Magro CM, Poe JC, Lubow M, Susac JO: Susac syndrome: an organ-specific autoimmune endotheliopathy syndrome associated with anti-endothelial cell antibodies. Am J Clin Pathol 2011, 136:903-1012.

13. Rennebohm RM, Susac JO: Treatment of Susac's syndrome. J Neurol SCi 2007, 257:215-220

14. Nagel MA, Forghani B, Mahalingam $R$, et al: The value of detecting anti-VZV IgG antibody in CSF to diagnose VZV vasculopathy. Neurology 2007, 68:1069-1073.

15. Nagel MA, Traktinskiy I, Azarkh Y, et al: Varicella zoster virus vasculopathy: analysis of virus-infected arteries. Neurology 2011, 77:364-370.

16. Gnann JW Jr: Varicella-Zoster virus: atypical presentations and unusual complications. J Infect Dis 2002, 186:S91-S98.

17. Venkataramana A, Pardo CA, McArthur JC, et al: Immune reconstitution inflammatory syndrome in the CNS of HIV-infected patients. Neurology 2006, 67:383-388.

18. Pagani JM, Duan JQ: Highly active antiretroviral therapy-induced immune recovery in an HIV-positive patient with a history of herpes zoster ophthalmicus. Optometry 2011, 82:77-82. 
19. Newsome SD, Nath A: Varicella-zoster virus vasculopathy and central nervous system immune reconstitution inflammatory syndrome with human immunodeficiency virus infection treated with steroids. J Neurovirol 2009, 15:288-291.

20. Chang CC, McLean C, Vujovic O, et al: Fatal acute varicella-zoster virus hemorrhagic meningomyelitis with necrotizing vasculitis in an HIV-infected patient. Clin Infect Dis 2009, 48:372-373.

doi:10.1186/1742-6405-10-22

Cite this article as: Ferretti et al:: Susac's syndrome as HIV-associated immune reconstitution inflammatory syndrome. AIDS Research and Therapy 2013 10:22.

\section{Submit your next manuscript to BioMed Central and take full advantage of:}

- Convenient online submission

- Thorough peer review

- No space constraints or color figure charges

- Immediate publication on acceptance

- Inclusion in PubMed, CAS, Scopus and Google Scholar

- Research which is freely available for redistribution 